\title{
Water restriction in seeds of Cereus jamacaru DC.
}

\author{
João Henrique Constantino Sales Silva ${ }^{1 *}{ }^{\circ}$, Gilvaneide Alves de Azerêdo ${ }^{1} \odot$, \\ Wagner de Melo Ferreira ${ }^{2} \oplus$, Vênia Camelo de Souza ${ }^{1}[0$

\footnotetext{
${ }^{1}$ Universidade Federal da Paraíba, Centro de Ciências Humanas, Sociais e Agrárias, Bananeiras, PB, Brasil. E-mail: joaohenriqueconst@gmail.com; azeredogil@yahoo.com.br; venia_camelo@hotmail.com

${ }^{2}$ Universidade Federal do Tocantins, Núcleo de Estudos Ambientais, Porto Nacional, TO, Brasil. E-mail: wmelouft@yahoo.com
}

ABSTRACT: Mandacaru (Cereus jamacaru DC.) is a cactus widely found in the Caatinga, with its seeds usually subjected to adverse conditions. Therefore, the objective of this study was to evaluate the effect of water restriction on germination and vigor of mandacaru seeds by using different salts and osmotic potentials. To that end, we used saline solutions of $\mathrm{NaCl}, \mathrm{KCl}, \mathrm{CaCl}_{2}$ and $\mathrm{MgCl}_{2}$ prepared at the osmotic potentials of $0.0 ;-0.2 ;-0.4 ;-0.6 ;-0.8 ;-1.0$ and $-1.2 \mathrm{MPa}$. Four replicates of 50 seeds per treatment were used, distributed in "gerbox" boxes between blotter paper and under temperature of $25^{\circ} \mathrm{C}$. Counts of the number of germinated seeds were performed daily for 21 days after root protrusion. The variables analyzed were the following: water content (\%), germination (\%), mean germination time and normal seedlings (\%). A completely randomized following the factorial scheme $4 \times 7$ (salts $\times$ osmotic potentials) was employed. Results obtained suggest that mandacaru seeds show the ability to germinate in saline soils, a characteristic found in arid and semi-arid areas. Decreased osmotic potential promoted reductions in germination (\%) and vigor of Cereus jamacaru DC seeds. The $\mathrm{MgCl}_{2}$ salt was the one that most negatively affected the germination and initial seedling development.

Key words: Caatinga; Cactaceae; mandacaru; osmotic potentials; salinity

\section{Restrição hídrica em sementes de Cereus jamacaru DC.}

RESUMO: O mandacaru (Cereus jamacaru DC.) é uma cactácea de ampla ocorrência na Caatinga e as suas sementes geralmente estão submetidas à condições adversas. Assim sendo, objetivou-se avaliar o efeito da restrição hídrica sobre a germinação e 0 vigor de sementes de mandacaru em meios germinativos sob diferentes sais e potenciais osmóticos. Foram utilizados os sais $\mathrm{NaCl}, \mathrm{KCl}, \mathrm{CaCl}_{2}$ e $\mathrm{MgCl}_{2}$ nos potenciais osmóticos: 0,0; -0,2; -0,4; -0,6; -0,8; -1,0 e -1,2 MPa. Foram usadas quatro repetições de 50 sementes por tratamento, distribuídas em caixas tipo "gerbox" entre papel "mata borrão", sob a temperatura de $25^{\circ} \mathrm{C}$. As contagens do número de sementes germinadas foram realizadas diariamente durante 21 dias após a protrusão radicular. As variáveis analisadas foram: teor de água (\%), germinação (\%), tempo médio de germinação e plântulas normais (\%). 0 delineamento foi inteiramente casualizado seguindo o esquema fatorial $4 \times 7$ (sais $\times$ potenciais osmóticos). Os resultados obtidos sugerem que as sementes de mandacaru são capazes de germinar em solos salinos, característica observada em áreas áridas e semiáridas. $O$ decréscimo do potencial osmótico provocou redução da germinação e do vigor das sementes de Cereus jamacaru DC. O sal $\mathrm{MgCl}_{2}$ foi o que mais afetou a germinação e o desenvolvimento inicial das plântulas.

Palavras-chave: Caatinga; Cactaceae; mandacaru; potenciais osmóticos; salinidade

\footnotetext{
* João Henrique Constantino Sales Silva - E-mail: joaohenriqueconst@gmail.com (Corresponding author)

Associate Editor: Maria Cileide Medeiros Coelho
} 


\section{Introduction}

In Brazil, 474 cacti species are found distributed throughout its national territory, with 200 of these considered as endemic species of Brazilian ecosystems (Zappi \& Taylor, 2020). Mandacaru (Cereus jamacaru DC.) is a native Cactaceae from the Caatinga and has great importance for sustainability and conservation of biodiversity of this said biome (Rêgo et al., 2009). These plants, besides having a great physiological adaptation, surviving prolonged droughts, also have ornamental, forage, medicinal and industrial potentials (Sales et al., 2014).

Commonly known as "cardeiro", this cactus has its shape resembling a candelabrum; with white flowers and reddish fruit, also covered with spines, which have the function of protection against predatory animals and physiological adaptation to low water availability (Santos \& Souza, 2016). Moreover, natural polymers extracted from this cactus are efficient coagulation/flocculation aids, becoming an alternative for water treatment especially in the Brazilian semiarid region, where its occurrence is abundant (Zara et al., 2012).

This mandacaru has the vegetative reproduction as its main form of reproduction, as it favors the rapid multiplication of accessions; however, seed propagation also is extremely important, bearing in mind the genetic diversity occurring in this process due to the genetic recombination of parental materials (Guedes et al., 2009). According to Meiado et al. (2017), research covering knowledge about the morphology and physiology of seeds and seedlings of Cactaceae are considered as extremely recent in Brazil, with few species having been studied so far.

The Northeastern semi-arid region of Brazil is characterized by areas with water stress either due to climatic reasons or due to soil type conditions. There is also a tendency in accumulating salts in the soil in these environments, released from minerals of the parent material (plagioclase), mainly the cations $\mathrm{Ca}^{+2}, \mathrm{Mg}^{+2}, \mathrm{Na}^{+}, \mathrm{K}^{+}$and anions $\mathrm{Cl}^{-}, \mathrm{SO}_{4}{ }^{2}, \mathrm{HCO}_{3}^{-}$and $\mathrm{CO}_{3}^{-2}$ (Ribeiro et al., 2009). Salt stress occurs when there is an excess of these elements in the soil, reducing the water potential and, consequently, preventing water absorption by the seeds and the root system (Medeiros, 2019).

Seed germination and seedling growth are the stages of plant development most sensitive to salinity. Salt stress causes adverse physiological and biochemical changes in the seeds during germination, being able to affect even the establishment of the individual by means of osmotic stress, ion-specific effects, and oxidative stress, which hinder water absorption or facilitate ion penetration into cells (Ibrahim, 2016; Bhatla \& Lal, 2018). Some compounds have been successfully used in research to simulate water restriction effects caused by salts on plants and seeds under laboratory conditions, such as $\mathrm{NaCl}, \mathrm{CaCl}_{2}$, and $\mathrm{KCl}$ (Medeiros, 2019). Therefore, knowledge on the tolerance of seeds to water deficit caused by different salts is extremely important, as it enables an understanding about the establishment of plant populations as well as how to exploit them.
Given the importance of mandacaru for the Northeastearn arid and semi-arid regions and aiming to provide more subsidies for understanding the germination behavior of its seeds under adverse conditions, the objective of the present research was to evaluate whether water restriction caused by different salts and osmotic potentials has influence on germination and vigor of seeds from this species.

\section{Materials and Methods}

This research was conducted in the Seed Technology Laboratory of the Center of Social Human and Agrarian Sciences of the Federal University of Paraiba, Campus III, Bananeiras - PB. Used seeds were from reddish fruit, a characteristic indicating it is ready to be harvested (Melo et al., 2017), collected in April 2018, in an experimental area part of the Brazilian Semi-Arid National Institute (INSA) in the municipality of Campina Grande - PB. Fruit pulping took place in the laboratory soon after the collection by maceration the fruit in a sieve, with subsequent washing under running water. Then, seeds were put to dry on paper, for three days, on the laboratory bench. After this period, seeds were kept in paper packages until conduction of the experimental test, one week after fruit processing.

In order to simulate the water deficit, four salt types were used $\left(\mathrm{NaCl}, \mathrm{KCl}, \mathrm{CaCl}_{2}\right.$ and $\left.\mathrm{MgCl}_{2}\right)$ and the prepared solutions were in the following osmotic potentials: 0.0 (distilled water); $-0.2 ;-0.4 ;-0.6 ;-0.8 ;-1.0$ and $-1.2 \mathrm{MPa}$, according to the Van't Hoff equation (Salisbury \& Ross, 1991). Seeds were set to germinate between pieces of "blotting paper", previously sterilized and moistened only once with the salt solutions at 2.5 times their dry weight, with two sheets at the base and one over the seeds, then kept in a germinator of the Biochemical Oxygen Demand (BOD) type under the temperature of $25^{\circ} \mathrm{C}$ and photoperiod of 12 hours. Four replicates of 50 seeds were used, distributed in transparent plastic "gerbox" boxes with dimensions of $11 \times 11 \times 3.5 \mathrm{~cm}$.

Germinated seeds were daily counted for 21 days after the radicle emergence, the criterion established for germination. These following variables were analyzed: determination of seed water content, germination percentage, mean germination time (Labouriau, 1983) and percentage of normal seedlings. Water content of the seeds was determined before sowing by using four replicates of 100 seeds each, weighed on a $0.0001 \mathrm{~g}$ precision scale and dried using the oven method at $105{ }^{\circ} \mathrm{C}$ for 24 hours (Brazil, 2009). The statistical design used was entirely randomized and followed a $4 \times 7$ factorial design (salts $\times$ osmotic potentials).

Statistical analyses were with the ESTAT/Jaboticabal ${ }^{\circ}$ and Microcal Origin 6.0 softwares. First, the polynomial equations were fit, yet due to occurrence of negative estimates for some characteristics, data were analyzed using the graphical program Origin 6.0 by the nonlinear logistic model, as according to the methodology used by Pôrto et al. (2006), whose adopted model was the Logistic 1 (Equation 1). 


$$
y=\frac{a}{1+e^{-k(x-x c)}}
$$

In which: $y=$ value of the characteristic for a given $x$ value (osmotic potential); $a=$ maximum value of $y$ characteristic; $k$ $=$ relative growth rate (in case of y reduction); $e=$ neperian logarithm base; $x c=$ value of $x$ (osmotic potential) that provides a $50 \%$ reduction in the maximum value of the characteristic, corresponding to the osmotic potential at the inflection point of the curve.

\section{Results and Discussion}

During the experiment, the water content of seeds was around $18 \%$ due to the recent fruit pulping. Regression and fit equations due to the negative estimates found, as well as the $R^{2}$ values are all illustrated in Table 1 .

According to Figure 1, the percentage of seed germination decreased as a function of reduced osmotic potentials, regardless of the analyzed salt. $\mathrm{MgCl}_{2}$ was the less favorable to germination and initial seedling development, since there was a drastic decrease in the germination percentage from the concentration level of $0.0(98 \%)$ to $2 \%$ at the $-0.8 \mathrm{MPa}$ potential. However, for $\mathrm{KCl}$, there was a marked tolerance of the seeds regarding this variable up to the $-0.8 \mathrm{MPa}$ potential, with germination higher than $80 \%$, thus indicating greater seed resistance to the effects of this salt at more negative osmotic potentials. Ortiz et al. (2019) found that C. jamacaru seeds, when subjected to water stress induced by polyethylene glycol, reduced their germination potential at osmotic potentials lower than 0.0 , with no germination observed at -1.0 MPa.

Using saline solutions at different osmotic potentials is, according to Taiz et al. (2017), necessary in order to obtain data that can be indicators in defining the species tolerance degree to saline conditions. Salinity reduces the potential

Table 1. Estimating equations of germination, mean germination time and percentage of normal seedlings of Cereus jamacaru DC. subjected to different osmotic potentials (-MPa) induced with $\mathrm{NaCl}, \mathrm{KCl}, \mathrm{CaCl}_{2}$ and $\mathrm{MgCl}_{2}$.

\begin{tabular}{ll}
\hline \multicolumn{1}{c}{ Equation } & $\mathbf{R}^{\mathbf{2}}$ \\
Germination (\%) & 0.99 \\
$\mathrm{NaCl}=95.56 /\left(1+\mathrm{e}^{26.97(x-0.82)}\right)$ & 0.99 \\
$\mathrm{KCl}=97.37 /\left(1+\mathrm{e}^{46.78(x-0.84)}\right)$ & 0.99 \\
$\mathrm{CaCl}_{2}=97.82 /\left(1+\mathrm{e}^{11.79(x-0.73)}\right)$ & 0.99 \\
$\mathrm{MgCl}_{2}=94.58 /\left(1+\mathrm{e}^{12.29(x-0.48)}\right)$ & \\
\hline $\mathrm{Mean}$ germination time (MGT) & 0.64 \\
$\mathrm{NaCl}=3.0048+20.3589 \mathrm{x}-19.6756 \mathrm{x}^{2}$ & 0.48 \\
$\mathrm{KCl}=2.4457+18.3870 \mathrm{x}-17.3325 \mathrm{x}^{2}$ & 0.36 \\
$\mathrm{CaCl}=0.6961+32.1151 \mathrm{x}-22.9166 \mathrm{x}^{2}$ & 0.56 \\
$\mathrm{MgCl}_{2}=2.3425+33.1968 \mathrm{x}-29.9546 \mathrm{x}^{2}$ & \\
\hline $\mathrm{Percentage} \mathrm{of} \mathrm{Normal} \mathrm{Seedlings}(\%)$ & 0.99 \\
$\mathrm{NaCl}^{2} 67.95 /\left(1+\mathrm{e}^{10.65(x-0.73)}\right)$ & 0.95 \\
$\mathrm{KCl}^{2} 54.50 /\left(1+\mathrm{e}^{33.44(x-0.84)}\right)$ & 0.98 \\
$\mathrm{CaCl}_{2}=63.98 /\left(1+\mathrm{e}^{7.69(x-0.63)}\right)$ & 0.97 \\
$\mathrm{MgCl}_{2}=76.5 /\left(1+\mathrm{e}^{99.07(x-0.42)}\right)$ & \\
\hline
\end{tabular}

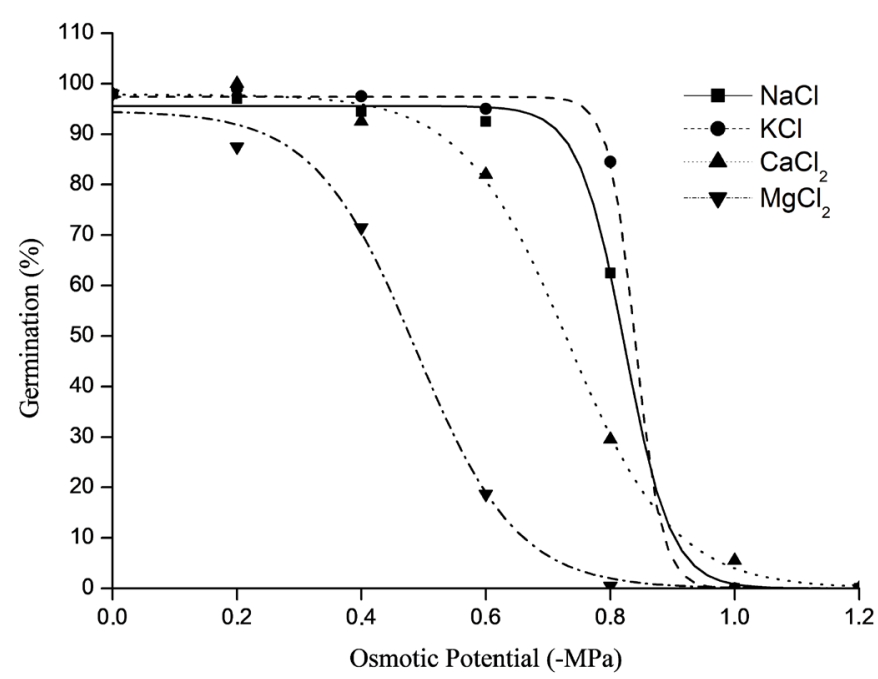

Figure 1. Effect of different salt concentrations on the germination percentage of seeds from Cereus jamacaru DC.

gradient between the soil and seed surface, restricting water absorption by the seed and thus reducing the germination rates (Schossler et al., 2012). Under high salt concentrations, when ions are absorbed and accumulate in seed tissues they can cause protein denaturation and membrane destabilization by reducing the hydration in these macromolecules. However, $\mathrm{Na}^{+}$is a more powerful denaturant than $\mathrm{K}^{+}$(Taiz et al., 2017).

Between the potentials of $-0.6 \mathrm{MPa}$ and $-0.8 \mathrm{MPa}$ a $30 \%$ reduction occurred in the germination percentage of seeds submitted to $\mathrm{NaCl}$. This decrease was even more pronounced when $\mathrm{CaCl}_{2}$ was used, reducing about $52.5 \%$. As for using this salt $\left(\mathrm{CaCl}_{2}\right)$, around $7 \%$ of seed germination was still verified at -1.0 MPa potential (Figure 1). According to Ibrahim (2016), salinity delays or prevents seed germination by several factors, such as reduced water availability and changes in the mobilization of stored reserves, also affecting the protein structural organization. Therefore, the lower the osmotic potential is, the lower the respiratory rate and the energy production are, which are necessary for the germination process (Farias et al., 2009).

A mechanism of osmotic adjustment consists in the increased synthesis process of membrane proteins involved in the water movement between intracellular and extracellular media, and these proteins are named aquaporins (Hasegawa et al., 2000; Smart et al., 2001). According to these authors, aquaporins increase membrane permeability, acting as mediators of the transport of water molecules towards the water gradient.

During the investigation of the germination and vigor of $C$. jamacaru seeds subjected to salt stress with $\mathrm{NaCl}$, Meiado et al. (2010) observed approximately a $54.5 \%$ germination rate at $-0.8 \mathrm{MPa}$ potential, slightly lower than the found in this study (62.5\%). These authors also inferred that this percentage of germinated seeds may indicate that the species is able to germinate in soils with high salinity, and may be considered a halotolerant species. Hence, it is possible this germination behavior to water and salt stress may be responsible for the abundant occurrence and wide distribution of the 
species in areas of Caatinga, since as according to the same abovementioned author, these characteristics demonstrate an adaptation to arid and semi-arid ecosystems, making them advantageous in these said environments.

In the ecophysiology study of seed germination from three species of Discocactus Pfeiff. (Cactaceae) subjected to different PEG 6000 solutions, Nascimento et al. (2018), observed that seed germination decreased up to the -0.6 MPa potential. A sharp reduction occurred in the germination percentage of the species belonging to this genus as the PEG 6000 solution concentration was raised. For the species $D$. bahiensis, $D$. zehntneri ssp. zehntneri and D. zehntneri ssp. petr-halfari, the germination percentages decreased around 76, 94 and 94\%, respectively, at the $-0.6 \mathrm{MPa}$ potential. From this potential on there was no germination.

During the evaluation of whether increased temperature reduces water stress tolerance in the germination of Pereskia grandifolia Haw. (Cactaceae) seeds while using polyethylene glycol (PEG 6000) to simulate the water deficit, Oliveira et al. (2017) found a decrease in seed germination rate with the osmotic potential reduction, regardless of the evaluated temperature. However, the increased temperature reduced the water stress tolerance in the germination of $P$. grandifolia seeds. Even though temperature regimes under water restriction conditions were not tested in the present study with mandacaru seeds, it is interesting to evidence that the reduced germination occurred as the osmotic potentials were decreased, under these mentioned conditions and regardless of high temperatures or not.

With concern to the mean germination time (MGT) (Figure 2 ), the data fitted the quadratic model. Considering all tested salts, an increased MGT was observed as the osmotic potential became more negative, going from 4 days $(0.0 \mathrm{MPa})$ to 10 $(\mathrm{KCl}$ and $\mathrm{NaCl})$, to $15\left(\mathrm{CaCl}_{2}\right)$ and to 17 days $\left(\mathrm{MgCl}_{2}\right)$ when the potential was of $-0.8 \mathrm{MPa}$. The highest MGT values were in the $\mathrm{MgCl}_{2}$ salt treatment up to the $-0.8 \mathrm{MPa}$ potential. From there onwards, a MGT decrease occurred in all salts until reaching

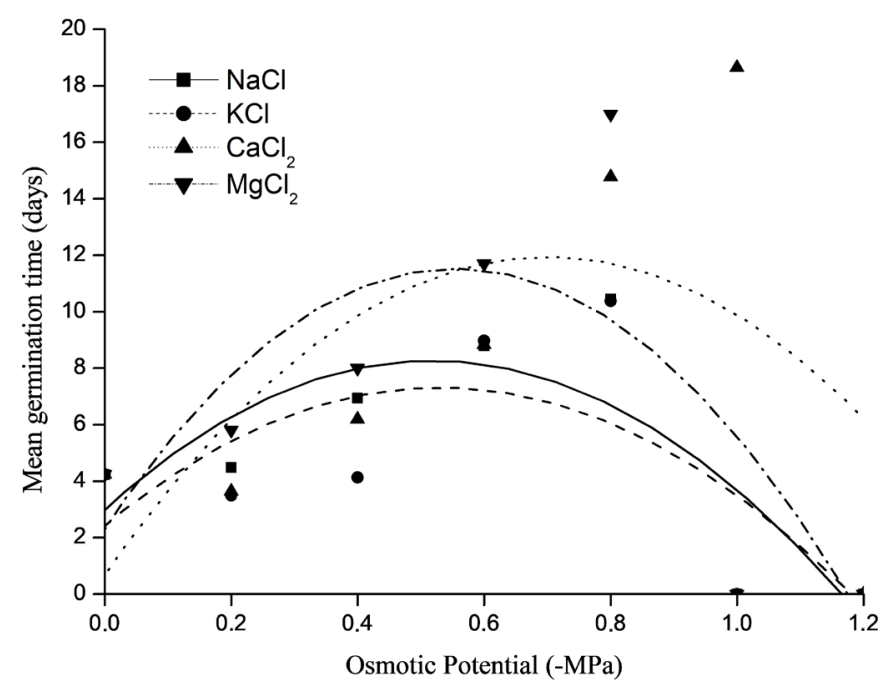

Figure 2. Effect of different salt concentrations on the mean germination time (MGT) of seeds from Cereus jamacaru DC. zero at the -1.0 MPa potential (points observed), with the exception of $\mathrm{CaCl}_{2}$, having a $7 \%$ germination percentage (Figure 1 ) at this potential. However, seeds that germinated at -1.0 $\mathrm{MPa}\left(\mathrm{CaCl}_{2}\right)$ took around 19 days to emit the root protrusion. In this study, reduced water availability and increased saline concentration affected germinability, promoting a slower and irregular germination of mandacaru seeds.

When evaluating the influence of the salts $\mathrm{NaCl}, \mathrm{KCl}, \mathrm{CaCl}_{2}$ and $\mathrm{MgCl}_{2}$ on the seed germination of chia (Salvia hispanica L. - Lamiaceae), Stefanello et al. (2020) concluded that $\mathrm{CaCl}_{2}$ and $\mathrm{MgCl}_{2}$ had a negative effect on germination and vigor of seeds when compared to $\mathrm{NaCl}$ and $\mathrm{KCl}$. In other words, the chemical differences between these salts can cause changes in the results of germination and vigor of seeds, even when at similar osmotic potentials (Souza \& Cardoso, 2000).

According to Brown et al. (2016), the ease that electrons can be removed from an atom or an ion has great impact on its chemical behavior due to the ionization energy, which is the minimal required energy to remove an electron from the valence band of an atom or ion of a chemical element. In this research, the negative effect on the studied variables was greater with increased ionization energy of the metal from each salt in the following order: $\mathrm{K}<\mathrm{Na}<\mathrm{Ca}<\mathrm{Mg}$, thus leading to an increased energy expenditure of the seed according to the increased ionization energy. Another possible explanation for the negative effect of dibasic or bivalent salts $\left(\mathrm{CaCl}_{2}\right.$ and $\mathrm{MgCl}_{2}$ ) when compared to monobasic or monovalent ones $(\mathrm{NaCl}$ and $\mathrm{KCl})$, besides the slower dissociation due to the higher ionization energy required to remove the second electron, is the higher concentration of negative chloride ions $(\mathrm{Cl})$ in the germination medium. That concetration is twice as high when compared to monovalent salts, thus increasing the negative character of the solution, which can influence a higher energy expenditure by the seed in the absorption of cations involved in the germination process. In other words, negative ions in the solution, with the dissociation of dibasic salts, will strongly attract these cations to themselves, due to their positive charge, thus hindering the cation transport in the medium.

Stefanello et al. (2018) also found that the effects of $\mathrm{MgCl}_{2}$ and $\mathrm{CaCl}_{2}$ salts on seed germination of thyme (Thymus vulgaris L. - Lamiaceae) were more pronounced than the effects promoted by $\mathrm{NaCl}$ and $\mathrm{KCl}$ salts. Moraes \& Menezes (2003), when studying the performance of soybean (Glycine max (L) Merrill - Fabaceae) seeds under different osmotic potential conditions, found that the effect of reducing osmotic potentials on the seeds depends on the salt type and its concentration. According to these authors, $\mathrm{MgCl}_{2}$ was the salt that hindered the most the expression of the seed physiological quality when compared to $\mathrm{NaCl}$ and $\mathrm{KCl}$, with vigor more affected than germination, thus corroborating the results found here with mandacaru seeds.

Regarding the percentage of normal seedlings (NS) (Figure 3 ), when the blotting paper was moistened with $\mathrm{MgCl}_{2}$ solution until having the $-0.4 \mathrm{MPa}$ potential, the NS percentage reached $65 \%$. From the $-0.6 \mathrm{MPa}$ osmotic potential on, there was no 


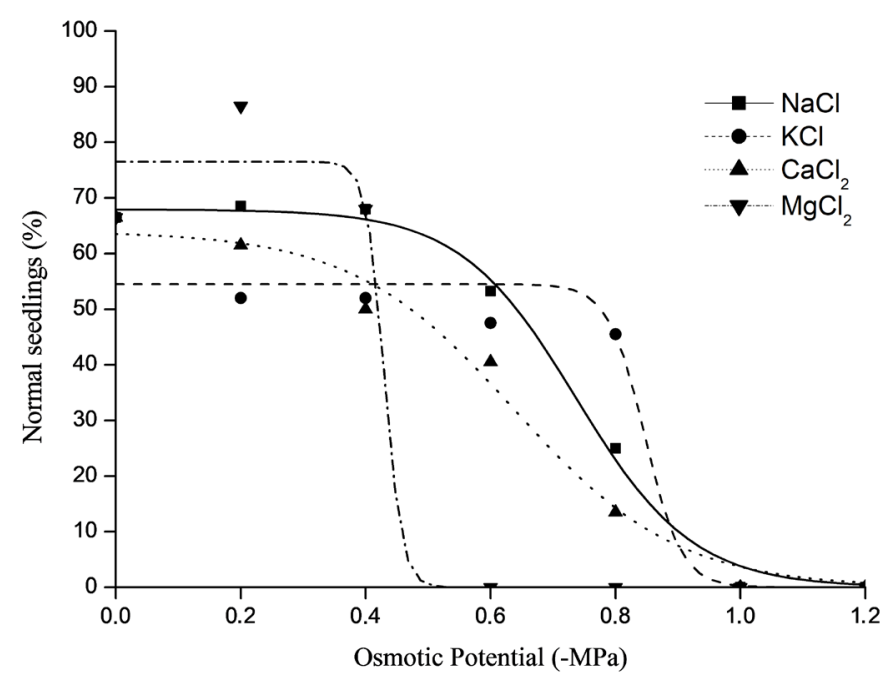

Figure 3. Effect of different salt concentrations on the percentage of normal seedlings percentage of Cereus jamacaru DC.

occurrence of normal seedlings. An important fact is that at $-0.2 \mathrm{MPa}, \mathrm{KCl}$ had the lowest percentage of normal seedlings, around 52\%; however, this salt managed to keep itself until the $-0.8 \mathrm{MPa}$ potential, with a NS percentage around $45.5 \%$. Lowest NP rates were for the $\mathrm{NaCl}$ and $\mathrm{CaCl}_{2}$ salts at $-0.8 \mathrm{MPa}$, with 25 and $14 \%$ respectively.

According to Larcher (2000), germination is most successful in environments of salt-free or low salt concentration. An excess of $\mathrm{Na}^{+}$, and especially $\mathrm{Cl}^{-}$, in the protoplasm causes disturbances in relation to the ion balance, as well as the specific effect of ions on the membranes. According to this author, if the adverse osmotic and ion-specific effects of salt absorption exceed the tolerance level of the plant, functional disturbances and injury take place. Extreme salt stress leads to dwarfism and inhibition of root growth, hereby resulting in abnormal seedlings.

At the end of the germination test, microorganisms were found on the paper (whose substrate had darkened), which may have contributed to the death of some seedlings at after 21 days of evaluation. Seed hydration leads to the release of solutes to the surrounding medium, such as sugars, organic acids, amino acids and various ions, which associated with the mild temperature of $25{ }^{\circ} \mathrm{C}$, may then stimulate emergence and growth of pathogens, thus causing seed and seedling deterioration (Bewley \& Black, 1994).

Fanti \& Perez (2004) also found a high fungus incidence when evaluating the effect of water and salt stresses on the viability and vigor of seeds from "paineira" (Chorisia speciosa St. Hil. - Bombacaceae). Also according to the authors, these seeds are more sensitive to $\mathrm{NaCl}$ and $\mathrm{CaCl}_{2}$. According to Lopes \& Lima (2015), many chemical and physiological processes of plants are altered by salinity and some species prevent the deleterious effects of salt by selective absorption, exclusion and or compartmentalization of salts, hence eliminating ions from the active sites of enzymes.

Using a bibliographic survey on Caatinga seeds, Dantas et al. (2014) concluded that most seeds from this biome present morphophysiological characteristics according to the localities where they originate. Also according to these authors, Caatinga seeds have specific adaptive characteristics, making them tolerant to several abiotic factors, especially to salt stress and, consequently, low water availability. Dantas (2019) makes some considerations in his study, stating that even though Caatinga seeds have demonstrated high tolerance to abiotic stresses, few have their limits known, such as when seeds stop germinating and the difference between accessions and/or populations inside and outside the Caatinga Biome concerning these tolerance limits.

The ability of mandacaru seeds in germinating and developing normal seedlings under water restrictions, up to a certain limit, suggests that this characteristic may favor the occurrence of this species in its natural environment, thus benefiting the recruitment of new individuals and, consequently, the perpetuation of the species. Results found here, albeit valuable, do not express the real tolerance of the seeds to hydric restriction under natural conditions, because these seeds, when under field conditions, are subject to the interaction of one or more abiotic factors.

\section{Conclusions}

Water restriction caused by salt solutions in the germination medium results in reduced germination and vigor in seeds of Cereus jamacaru DC.

$\mathrm{MgCl}_{2}$ was the less favorable salt to germination and initial development of seedlings for the studied variables, except for percentage of normal seedlings up to $-0.4 \mathrm{MPa}$.

Seeds demonstrate tolerance to the salts $\mathrm{KCl}, \mathrm{NaCl}$ and $\mathrm{CaCl}_{2}$ up to $-0.8 \mathrm{MPa}$; however, they can germinate up to -1.0 $\mathrm{MPa}$ when in presence of $\mathrm{CaCl}_{2}$.

Results found in this study suggest that Cereus jamacaru seeds are able to germinate in saline soils, which are characteristics found in arid and semi-arid areas.

\section{Acknowledgements}

We would like to thank Everton de Oliveira Teixeira for his invaluable contributions to this research, and the Center of Social Human and Agrarian Sciences from the Federal University of Paraíba (CCHSA/UFPB) as well as the Brazilian National Council for Scientific and Technological Development (CNPq) for the scholarship granted to the first author.

\section{Compliance with Ethical Standards}

Author contributions: Conceptualization: GAA; Data curation: JHCSS, GAA; Formal analysis: GAA; Funding acquisition: GAA; Investigation: JHCSS; Methodology: GAA, JHCSS; Project administration: GAA, JHCSS; Resources: GAA, VCS; Supervision: GAA; Validation: JHSS, GAA, WMF, VCS; Visualization: JHCSS, GAA, WMF, VCS; Writing - original draft: JHCSS, GAA, WMF, VCS; Writing - review \& editing: JHCSS, GAA, WMF, VCS. 
Conflict of Interest: The authors declare no conflict of interest.

Funding: The research grant awarded to the first author was financed by the Conselho Nacional de Desenvolvimento Científico e Tecnológico (CNPq).

\section{Literature Cited}

Bewley, J.D; Black, M. Seeds: physiology of development and germination. New York: Plemun Press, 1994. 445p.

Bhatla, S.C.; Lal, M.A. Plant Physiology, Development and Metabolism. Singapore: Springer, 2018. 1237p. https://doi.org/10.1007/978981-13-2023-1

Brasil. Ministério da Agricultura, Pecuária e Abastecimento. Regras para análise de sementes. Brasília: MAPA; ACS, 2009. 399 p.

Brown, T.L.; LeMay Júnior, H.E.; Bursten, B.E.; Murphy, C.J. Woodward, P.M.; Stoltzfus, M.W. Química: a ciência central. 13.ed. São Paulo: Pearson Education do Brasil, 2016. 1216p.

Dantas, B.F. Germinação de sementes da Caatinga em um clima futuro. In: Simpósio do Bioma Caatinga. 2., 2018, Petrolina. Anais... Petrolina: Embrapa Semiárido, 2019. p.126-133. (Embrapa Semiárido. Documentos, 287). http://ainfo.cnptia. embrapa.br/digital/bitstream/item/197111/1/Barbara.pdf. 03 Mar. 2020.

Dantas, B.F.; Matias, J.R.; Mendes, R.B.; Ribeiro, R.C. "As sementes da Caatinga são...": um levantamento das características das sementes da Caatinga. Informativo Abrates, v.24, n.3, p.1823, 2014. https://ainfo.cnptia.embrapa.br/digital/bitstream/ item/110327/1/Barbara-1.pdf. 03 Mar. 2020.

Fanti, S.C.; Perez, S.C.J.G.A. Processo germinativo de sementes de paineira sob estresses hídrico e salino. Pesquisa Agropecuária Brasileira, v.39, n.9, p.903-909, 2004. https://doi.org/10.1590/ S0100-204X2004000900010.

Farias, S.G.G.; Freire, A.L.O.; Santos, D.R.; Bakke, I.A.; Silva, R.B.E. Efeitos dos estresses hídrico e salino na germinação de sementes de gliricídia [Gliricidia sepium (JACQ.) STEUD.]. Revista Caatinga, v.22, n.4, p.152-157, 2009. https://periodicos.ufersa.edu.br/ index.php/caatinga/article/view/1329/pdf. 19 Mar. 2020.

Guedes, R.S.; Alves, E.U.; Gonçalves, E.P.; Bruno, R.L.A.; Braga Júnior, J.M.; Medeiros, M.S. Germinação de sementes de Cereus jamacaru DC. em diferentes substratos e temperaturas. Acta Scientiarum. Biological Sciences, v.31, n.2, p.159-164, 2009. https://doi.org/10.4025/actascibiolsci.v31i2.635.

Hasegawa, P.M.; Bressan, R.A.; Zhu J.K.; Bohnert, H.J. Plant cellular and molecular responces to high salinity. Annual Review of Plant Physiology and Plant Molecular Biology, v.51, n.1, p.463-499. 2000. https://doi.org/10.1146/annurev.arplant.51.1.463.

Ibrahim, E.A. Seed priming to alleviate salinity stress in germinating seeds. Journal of Plant Physiology, v.192, p.38-46, 2016. https:// doi.org/10.1016/j.jplph.2015.12.011.

Labouriau, L.G. A germinação das sementes. Washington: OEA, 1983. $173 p$.

Larcher, W. Ecofisiologia vegetal. São Carlos: RiMa Editora, 2000. $531 \mathrm{p}$.

Lopes, N.F.; Lima, M.G.S. Fisiologia da produção. Viçosa: Editora UFV, 2015. 492p.
Medeiros, J.X. Senna cana (Nees \& Mart.) H.S. Irwin \& Barneby: morfologia de frutos, sementes, plântulas, plantas jovens e ecofisiologia da germinação. Recife: Universidade Federal Rural de Pernambuco, 2019. 127p. Tese Doutorado. http://www. tede2.ufrpe.br:8080/tede2/handle/tede2/8221. 29 Mar. 2020.

Meiado, M.V.; Albuquerque, L.S.C.; Rocha, E.A.; Rojas-Aréchiga, M.; Leal, I.R. Seed germination responses of Cereus jamacaru DC. ssp. jamacaru (Cactaceae) to environmental factors. Plant Species Biology, v.25, n.2, p.120-128. 2010. https://doi.org/10.1111/ j.1442-1984.2010.00274.x.

Meiado, M.V.; Lima, A.T.; Nascimento, J.P.B.; Aona, L.Y.S. Avanços nos estudos sobre sementes e plântulas de cactos do Brasil. Gaia Scientia, v.11, n.4, p.88-113, 2017. https://doi.org/10.21707/ gs.v11.n04a10.

Melo, R.S.; Silva, S.M.; Sousa, A.S.B.; Lima, R.P.; Dantas, A.L.; Dantas, R.L.; Figueiredo, V.M.A. Maturação e qualidade de frutos de mandacaru (Cereus jamacaru P. DC.) de diferentes bioclimas do estado da Paraíba. Agropecuária Técnica, v.38, n.3, p.160-168, 2017. https://doi.org/10.25066/agrotec.v38i3.33818.

Moraes, G.A.F.; Menezes, N.L. Desempenho de sementes de soja sob condições diferentes de potencial osmótico. Ciência Rural, v.33, n.2, p.219-226, 2003. https://doi.org/10.1590/S010384782003000200007.

Nascimento, J.P.B.; Siqueira-Filho, J.Á.; Meiado, M.V. Seed germination of three endangered subspecies of Discocactus Pfeiff. (Cactaceae) in response to environmental factors. Journal of Seed Science, v.40, n.3, p.253-262, 2018. https://doi.org/10.1590/2317$1545 v 40 n 3183036$

Oliveira, D.M.; Lima, A.T.; Rocha, E.A.; Meiado, M.V. O aumento da temperatura reduz a tolerância ao estresse hídrico na germinação de sementes de Pereskia grandifolia Haw. subsp. grandifolia (Cactaceae)?. Gaia Scientia, v.11, n.4, p.26-36, 2017. https://doi. org/10.22478/ufpb.1981-1268.2017v11n4.35466.

Ortiz, T.A.; Urbano, M.R.; Takahashi, L.S.A. Effects of water deficit and $\mathrm{pH}$ on seed germination and seedling development in Cereus jamacaru. Semina: Ciências Agrárias, v.40, n.4, p.1379-1392, 2019. http://dx.doi.org/10.5433/1679-0359.2019v40n4p1379.

Pôrto, D.R.Q.; Cecílio Filho, A.B.; May, A.; Barbosa, J.C. Acúmulo de macronutrientes pela cebola 'Optima' estabelecida por semeadura direta. Horticultura Brasileira, v.24, n.4, p.470-475, 2006. https://doi.org/10.1590/S0102-05362006000400015.

Rêgo, M.M.; Araújo, E.R.; Rêgo, E.R.; Castro, J.P. In vitro seed germination of mandacaru (Cereus jamacaru DC.). Revista Caatinga, v.22, n.4, p.34-38, 2009. https://periodicos.ufersa.edu. br/index.php/caatinga/article/view/780/736. 16 Mar. 2020.

Ribeiro, M.R.; Barros, M.F.C.; Freire, M.B.G.S. Química dos solos salinos e sódicos. In: Melo, V.F, Alleoni, L.R.F. (Eds.). Química e mineralogia do solo. Parte II - Aplicações. Viçosa: Sociedade Brasileira de Ciência do Solo, 2009. p. 449-484.

Sales, M.S.L.; Martins, L.V.; Souza, I.; Meireles de Deus, M.S.; Peron, A.P. Cereus jamacaru de candolle (Cactaceae), o mandacaru do Nordeste brasileiro. Publicatio UEPG: Ciências Biológicas e da Saúde, v.20, n.2, p.135-142, 2014. https://doi.org/10.5212/ publicatio\%20uepg.v20i2.6353.

Salisbury, F.B.; Ross, C.W. Plant physiology. 4ed. Belmont: Wadworth, 1991. 682p. 
Santos, J.I.G.; Souza, D.D. O mandacaru como fonte alimentar para caprinos no período de seca no semiárido. Meio Ambiente e Sustentabilidade, v.9, n.5, p.5-14, 2016. https://www.uninter. com/cadernosuninter/index.php/meioAmbiente/article/ view/397/421. 19 Mar. 2020.

Schossler, T.H.; Machado, D.M.; Zuffo, A.M.; Andrade, F.D.; Piauilino, A.C. Salinidade: efeitos na fisiologia e na nutrição mineral de plantas. Enciclopédia Biosfera, v.8, n.15, p.1563-1578, 2012. http://www.conhecer.org.br/enciclop/2012b/ciencias\%20 agrarias/salinidade\%20efeitos.pdf. 29 Mar. 2020.

Smart, L.B.; Moskal, W.A.; Cameron, K.D.; Bennett, A.B. MIP genes are down-regulated under drought stress in Nicotiana glauca. Plant Cell Physiology, v.42, n.7, p.686-693, 2001. https://doi. org/10.1093/pcp/pce085.

Souza, G.M.; Cardoso, V.J.M. Effects of different environmental stress on seed germination. Seed Science and Technology, v.28, n.3, p.621-630, 2000. http://hdl.handle.net/11449/20224. 03 Mar. 2020.
Stefanello, R.; Viana, B.B.; Neves, L.A.S. Germinação de sementes de Thymus vulgaris submetidas ao estresse salino. Caderno de Pesquisa, v.30, n.2, p.19-27, 2018. https://doi.org/10.17058/ cp.v30i2.12220.

Stefanello, R.; Viana, B.B.; Goergen, P.C.H.; Neves, L.A.S.; Nunes, U.R. Germination of chia seeds submitted to saline stress. Brazilian Journal of Biology, v.80, n.2, p.285-289, 2020. https://doi. org/10.1590/1519-6984.192140.

Taiz, L.;Zeiger, E.; Møller, I.M.; Murphy, A. Fisiologia e desenvolvimento vegetal. 6.ed. Porto Alegre: Artmed, 2017. 858p.

Zappi, D.; Taylor, N. Cactaceae. In: Lista de Espécies da Flora do Brasil. Jardim Botânico do Rio de Janeiro. http://floradobrasil.jbrj.gov. br/reflora/floradobrasil/FB70. 16 Jul. 2020.

Zara, R.F.; Thomazini, M.H.; Lenz, G.F. Estudo da eficiência de polímero natural extraído do cacto mandacaru (Cereus jamacaru) como auxiliar nos processos de coagulação e floculação no tratamento de água. Revista de Estudos Ambientais, v.14, n.2, p.75-83, 2012. https://doi.org/10.7867/1983-1501.2012v14n2p75-83. 